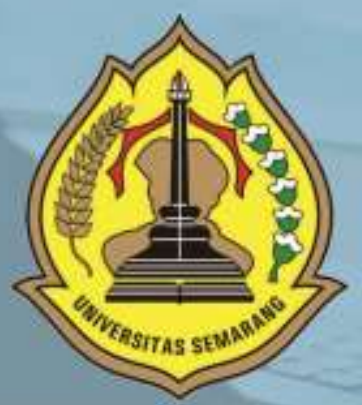

P-ISSN: 1412-5331, E-ISSN: 2716-2532 MAJALAH ILMIAH FAKULTAS EKONOMI UNIVERSITAS SEMARANG

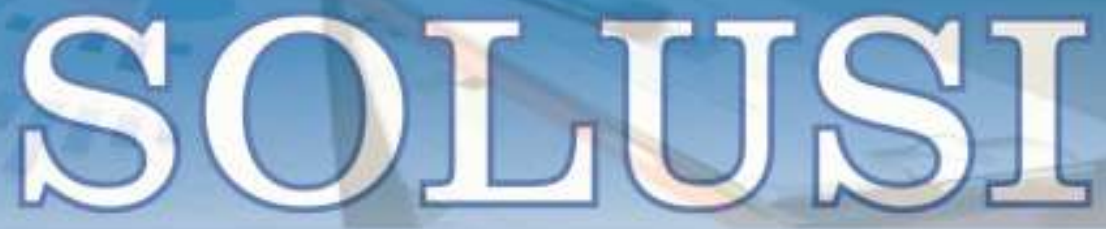

PENGARUH TINGKAT LITERASI KEUANGAN, SIKAP INDIVIDU TERHADAP MINAT INVESTASI SAHAM DI KALANGAN MAHASISWA S2 MAGISTER MANAJEMEN UNIVERSITAS SEMARANG (Asah Wiari Sidiq: Asih Niati - Universitas Semarang)

PENINGKATAN KINERJA PENGAJARAN DOSEN MELALUI KEPEMIMPINAN TRANSFORMASIONAL DAN PEMENUHAN KEBUTUHAN PSIKOLOGIS DASAR DENGAN PEMEDIASI MOTIVASI KER.JA (Anik Herminingsih - Universitas Mercu Buana)

PENGARUH PAJAK, TUNNELING INCENTIVE DAN GOOD CORPORATE GOVERNANCE (GCG) DAN MEKANISME BONUS TERHADAP INDIKASI TRANSFER PRICING PADA PERUSAHAAN MANUFAKTUR (Arum Sasi Andayani; Andiani Ika Sulistyanuati - Liniversitas Semarang)

PENGELOLAAN ALOKASI DANA DESA: AKUNTABILITAS DAN TRANSPARANSI (STUDI KASUS PADA DESA GINGGANGTANI, KECAMATAN GUBUG, KABUPATEN GROBOGAN) (Ana Rokhatt: Saifidin: Dian Trivani - Universitas Semarang)

PENERAPAN STRATEGI BAURAN PEMASARAN PADA USAHA KECIL TELUR ASIN DI KELURAHAN TEGAL SARI, KECAMATAN CANDI SARI, SEMARANG (Nisa Novia Avien Christy; Dwi Widi Pratito - Universitas Semarang)

FAKTOR-FAKTOR YANG MEMPENGARUHI PROFITABILITAS LEMBAGA PERKREDITAN DESA (LPD) DI KABUPATEN BADUNG (Ida Ayu Nyoman Yuliastuti, Putu Kepramareni, I Gusti Ayu Asta Yunisari - Universitas Mahasaraswati Denpasar)

KEBERHASILAN MEMPERTAHANKAN WARUNG MAKAN PRASMANAN MBAH SAN (Sri Wulandari: Susanto - Universitas Semarang)

BRAND PERSONALITY DAN GENDER BRAND PERSONALITY STRATEGI MEMBANGUN MEREK (Haris Murwanto - Universitas Semarang)

POLA PERMINTAN DAN PENAWARAN KETERSEDIAAN DAGING SAPI NASIONAL TAHUN 2030 DENGAN PENDEKATAN FORECASTING (Moeljono - Universitas Semarang)

PENGARUH BRAND IMAGE, KUALITAS PRODUK, PERSEPSI HARGA TERHADAP KEPUTUSAN PEMBELIAN (STUDI KASUS PADA PRODUK SUSU NATURSOYA CV. GLOBAL MANDIRI SEJAHTERA KANCA PURWODADI)

(Ajeng Ayr Fatimah P: Soedarmadi - Untversitas Semarang) 


\section{DESKRIPSI}

Majalah IImiah Solusi Mengkaji

Masalah-Masalah Sosial,

Ekonomi dan Bisnis

\section{KETERANGAN TERBIT}

Terbit Pertama Kali Juli 2002

dan SelanjutnyaTerbit Tiga Bulan

Sekali (Januari, April, Juli dan

Oktober)

\section{PENERBIT}

Fakultas Ekonomi USM

\section{ALAMAT PENERBIT}

JL. Soekarno Hatta Semarang

Telp. 024-6702757 Fax. 024-6702272

\section{PENGELOLA}

Editor in Chief : Yohanes Suhardjo, SE, M.Si., Ak, CA Vice Editor Chief : Sugeng Rianto, SE, MM

Managing Editor: Edy Suryawardana, SE, MM

Secretary of Managing Editor : Asih Niati, SE, MM

Administration \& Circulation :

Citra Rizkiana, SE, MM

Layout \& Typesetting : M Burhan Hanif S.Kom, M.Kom

Board of Editors:

1. Prof. Dr. Ir. Kesi Widjajanti, SE, MM (USM)

2. Prof. Drs. Mohammad Nasir, Msi, Ph.D, AK. (USM)

3. Prof. Supramono SE, MBA, DBA (UKSW)

4. Prof. Drs. H. Imam Ghozali, M.Com, Akt, PhD (UNDIP)

5. Prof. Dr. Agus Suroso, MS (UNSOED)

6. Prof. Dr. Widodo, SE, M.Si (UNISSULA)

7. Prof. Dr. Dra. Sulastri, ME, M.Kom (UNSRI)

8. Dr. Ardiani Ika S, SE, MM, Ak, CA, CPA (USM)

\section{KATA PENGANTAR}

Sungguh merupakan kebahagiaan tersendiri bagi kami, takala kami dapat hadir rutin setiap tiga bulan sekali untuk saling bertukar pikiran mengenai hal-hal baru dibidang sosial, ekonomi dan bisnis.

Pada kesempatan ini penerbit menyampaikan terima kasih kepada semua pihak yang telah mengirimkan artikel-artikelnya. Penerbit akan membuka kesempatan seluas-luasnya bagi seluruh kalangan akademisi maupun praktisi baik dari dalam maupun luar Universitas Semarang untuk mempublikasikan karya ilmiahnya.

Penerbitan majalah ilmiah "SOLUSI" kali ini menghadirkan 10 (Sepuluh) artikel yang kami anggap layak untuk diterbitkan, dengan harapan dapat menjadi tambahan referensi bagi para pembaca dan menjadi sumbangan pengembangan persemaian khasanah pengetahuan dibidang sosial, ekonomi dan bisnis.

Akhir kata semoga majalah ilmiah "SOLUSI" dapat memberi manfaat yang sebesar-besarnya.

Hormat Kami 


\section{DAFTAR ISI}

PENGARUH TINGKAT LITERASI KEUANGAN, SIKAP INDIVIDU

TERHADAP MINAT INVESTASI SAHAM DI KALANGAN MAHASISWA S2 MAGISTER MANAJEMEN UNIVERSITAS SEMARANG

(Asah Wiari Sidiq; Asih Niati - Universitas Semarang).......

PENINGKATAN KINERJA PENGAJARAN DOSEN MELALUI

KEPEMIMPINAN TRANSFORMASIONAL DAN PEMENUHAN KEBUTUHAN PSIKOLOGIS DASAR DENGAN PEMEDIASI MOTIVASI KERJA

(Anik Herminingsih - Universitas Mercu Buana)

PENGARUH PAJAK, TUNNELING INCENTIVE DAN GOOD CORPORATE GOVERNANCE (GCG) DAN MEKANISME BONUS TERHADAP INDIKASI TRANSFER PRICING PADA PERUSAHAAN MANUFAKTUR

(Arum Sasi Andayani; Ardiani Ika Sulistyawati - Universitas Semarang)

PENGELOLAAN ALOKASI DANA DESA: AKUNTABILITAS DAN TRANSPARANSI

(STUDI KASUS PADA DESA GINGGANGTANI, KECAMATAN GUBUG, KABUPATEN GROBOGAN)

(Ana Rokhati; Saifudin; Dian Triyani - Universitas Semarang).

PENERAPAN STRATEGI BAURAN PEMASARAN PADA USAHA KECIL TELUR ASIN DI KELURAHAN TEGAL SARI, KECAMATAN CANDI SARI, SEMARANG

(Nisa Novia Avien Christy; Dwi Widi Pratito - Universitas Semarang)

FAKTOR-FAKTOR YANG MEMPENGARUHI PROFITABILITAS LEMBAGA PERKREDITAN DESA (LPD) DI KABUPATEN BADUNG

(Ida Ayu Nyoman Yuliastuti; Putu Kepramareni; I Gusti Ayu Asta Yunisari - Universitas Mahasaraswati Denpasar)..... .75

KEBERHASILAN MEMPERTAHANKAN WARUNG MAKAN PRASMANAN MBAH SAN

(Sri Wulandari; Susanto - Universitas Semarang).....

BRAND PERSONALITY DAN GENDER BRAND PERSONALITY STRATEGI MEMBANGUN MEREK

(Haris Murwanto - Universitas Semarang).

POLA PERMINTAN DAN PENAWARAN KETERSEDIAAN DAGING SAPI NASIONAL TAHUN 2030 DENGAN PENDEKATAN FORECASTING

(Moeljono - Universitas Semarang)......

PENGARUH BRAND IMAGE, KUALITAS PRODUK, PERSEPSI HARGA TERHADAP KEPUTUSAN PEMBELIAN (STUDI KASUS PADA PRODUK SUSU NATURSOYA CV. GLOBAL MANDIRI SEJAHTERA KANCA PURWODADI)

(Ajeng Ayu Fatimah P; Soedarmadi - Universitas Semarang) 


\title{
POLA PERMINTAN DAN PENAWARAN KETERSEDIAAN DAGING SAPI NASIONAL TAHUN 2030 DENGAN PENDEKATAN FORECASTING
}

\author{
Moeljono \\ sastro@usm.ac.id \\ Fakultas Ekonomi Universitas Semarang
}

Diterima: November 2019, Disetujui:Desember 2019,Dipublikasikan: Januari 2020

\begin{abstract}
The availability of beef is important influence on beef self-sufficiency program launched by the government. With the availability of beef in Indonesia, the government program will be done by properly. Indonesia must be learning from the failure of beef self-sufficiency program, 3 times of self-sufficiency 3 times failed. Government and society has long dreamed of repeating the success as exporting countries such as in 1970.

The objective of this research is (1) to compare the suplay and demand beef in 2010-2018, (2) to analyzethe comparison between the availability of beef in 2030 with beef consumptionin 2030 in the national. The method analyze is (1) descriptive analisys and (2) method of forecasting analysis conducted in case study. The result of research showed (1) ratio between the suplay and demand of beef in 20102018, is different every year, the first year until the fourt years that suplay in bigger than demadn, and the other years that demand is bigger than suplay, (2) availability and demand of beef in Indonesian in 2030 experienced a rising trend and ratio with the availability of national beef demand in 2030 shows the ratio of the availability of beef bigger than the suplay of beef.

Keyword: Analysis of Forecasting, Trend, Beef Availability, Beef Consumption
\end{abstract}

\begin{abstract}
ABSTRAK
Ketersediaan daging sapi berpengaruh penting terhadap program swasembada daging sapi yang dicanangkan oleh pemerintah. Dengan tersedianya jumlah daging sapi di Indonesia maka program pemerintah tersebut akan terlaksana dengan baik.Indonesia perlu belajar dari kegagalan program swasembada daging sapi, 3 kali swasembada 3 kali gagal. Pemerintah dan masyarakat sejak lama bermimpi mengulang sukses sebagai negara pengekspor sapi seperti pada era tahun 1970-an.

Tujuan penulisan adalah (1)untuk mengetahui perbandingan antara produksi daging sapi dan konsumsi daging sapi tahun 2010-2018, (2) Untuk menganalisis perbandingan antara penawaran daging sapi dengan permintaan daging sapi di tahun 2030 secara nasional. Metode analisis yang digunakan (1) analisis deskriptif; (2) metode analisis forecasting. Hasil pengujian (1) perbandingan antara penawaran dan permintaan daging sapi tahun 2010-2018 setaip tahunnya berbeda yaitu pada empat tahun pertama penawaran lebih besar dibanding permintaan, pada lima tahun terakhir, permintaan lebih besar dibanding penawaran, (2) penawaran dan permintaan daging sapi nasional tahun 2030 mengalami trend kenaikan dan perbandingan produksi dengan konsumsi daging sapi nasional 2030 menunjukkan rasio permintaan daging sapi lebih besar dibandingkan dengan penawaran daging sapi.

Kata kunci: Analisis Forecasting, Trend, Ketersediaan Daging Sapi, Konsumsi Daging Sapi
\end{abstract}

\section{PENDAHULUAN}

\section{Latar Belakang}

Thomas Robert Malthus (1798), menyatakan bahwa pertumbuhan manusia dihitung memakai deret ukur sedangkan produksi pangan dihitung memakai deret hitung. Melihat argumentasi Malthus, dunia akan terjadi kekurangan pangan karena pertumbuhan produksi pangan tidak sebanding dengan pertumbuhan penduduk. Menjawab argumentasi yang dikemukakan oleh Malthus, terjawab dengan adanya 
tekhnologi. Dengan adanya teknologi produksi pangan memang meningkat, namun belum bisa memenuhi kebutuhan akan pangan bagi manusia.

Pendapat Malthus, terbukti di Indonesia sampai saat ini kebutuhan akan pangan belum bisa terpenuhi. Salah satunya adalah produksi pangan berasal dari hewani yakni daging sapi. Permintaan komsusi daging sapi terus meningkat seiring meningkatnya jumlah penduduk dan kesejahteraan masyarakat (Putro, 2008). Bagi masyarakat, daging sapi masih termasuk barang mewah dengan ciri permintaannya responsif terhadap perubahan harga dan merupakan barang normal dengan ciri kenaikan pendapatan penduduk menyebabkan permintaannya semakin meningkat. Namun, daging sapi memiliki harga tipikal yang cenderung naik, yakni ketika harga daging di pasaran naik, tidak akan turun lagi walaupun ketersedian daging di rasa cukup.

Dimasa datang permintaan akan komsusi daging sapi semakin meningkat seiring dengan meningkatnya pertumbuhan penduduk dan pertumbuhan ekonomi, yang berdampak pada meningkatnya kesejahteraan masyarakat. Berikut jumlah penduduk, Penawaran daging sapi nasional dan Permintaan daging sapi nasional tahun 2010-2018, seperti tertera pada tabell.

Tabel 1 Jumlah Penduduk, Produksi dan Komsusi Daging Sapi Nasional

\begin{tabular}{ccccc}
\hline Tahun & Penduduk $^{\mathbf{1}}$ & Produksi $^{\mathbf{2}}$ & Komsusi $^{\mathbf{3}}$ & $(-/+)^{\mathbf{4}}$ \\
\hline 2010 & $238.518 .800,00$ & $436.450 .000,00$ & $392.168 .240,79$ & $44.281 .759,21$ \\
2011 & $241.990 .700,00$ & $485.335 .000,00$ & $422.477 .051,41$ & $62.857 .948,59$ \\
2012 & $245.425 .200,00$ & $508.905 .000,00$ & $445.166 .469,04$ & $63.738 .530,96$ \\
2013 & $248.818 .100,00$ & $504.819 .000,00$ & $495.079 .804,86$ & $9.739 .195,14$ \\
2014 & $252.164 .800,00$ & $497.669 .000,00$ & $541.767 .952,96$ & $(44.098 .952,96)$ \\
2015 & $255.461 .700,00$ & $506.660 .000,77$ & $583.272 .004,48$ & $(76.612 .003,71)$ \\
2016 & $258.705 .000,00$ & $518.484 .000,03$ & $649.258 .549,70$ & $(130.774 .549,67)$ \\
2017 & $261.890 .900,00$ & $486.320 .000,00$ & $687.088 .964,48$ & $(200.768 .964,48)$ \\
2018 & $265.015 .300,00$ & $496.302 .000,00$ & $708.056 .222,24$ & $(211.754 .222,24)$
\end{tabular}

Sumber :

${ }^{12}$ Kementrian Perdagangan. 2014.

${ }^{3}$ BPS. 2018. Proyeksi Penduduk Indonesia 2015-2045. BPS. Jakarta.

Indonesia

${ }^{4}$ Hasil Perhitungan Penulis 2019 
Pada Tabel 1. Memperlihatkan bahwa penawaran melalui produksi daging sapi nasional mampu memenuhi permintaan kebutuhan daging sapi pada tahun 2010 sampai 2013. Mulai tahun 2014 hingga 2018 pola penawaran cenderung fluktuatif, hal berbeda ditujukan pada sisi permintaan dan jumalh penduduk yang terus meningkat secara konsisten. Perilaku pola permintaan dan penawaran yang demikian menjadikan semakin curamnya selisih angka antara permintaan dan penawaran.

Adanya fenomena tersebut pemerintah mengeluarkan berbagai paket kebijakan yang intinya adalah program swasembada daging tercapai, adapun paket kebijakan yang dikeluarkan oleh pemerintah adalah program pengembangan ternak sapi seperti kredit massal (1972-1983), kredit bukan massal (1979-1983 dan 1987-1989), Kredit Usaha Tani (KUT) (1992), dengan mewajibkan perusahaan peternakan untuk bermitra usaha dengan peternakan rakyat (SK Kementan no 472/1996), kredit Penyertaan Modal ventura Daerah (PMvD), hingga Kredit Ketahanan Pangan dan energi (KKPe) dan pendamping Program Swasembada Daging Sapi (PSDS) 2009 dan 2014 yaitu Kredit Usaha Pembibitan Sapi (KUPS) yang sampai saat ini masih berlangsung. Namun, semuanya gagal.

Hukum permintaan mengatakan bahwa semakin tinggi permintaan maka harga barang tersebut akan semakin mahal. Demikian pula yang terjadi pada tingginya permintaan terhadap ketersediaan daging sapi dalam negeri yang menyebabkan harga daging sapi dalam negeri tinggi. Mengutip data dari Pusat Data dan Sistem Informasi Pertanian Kementerian Pertanian, (2018), bahwa perkembangan harga daging sapi di tingkat konsumen sejak tahun 1983 hingga tahun 2017 cenderung terus meningkat ratarata sebesar 12,75 persen per tahun. Peningkatan tertinggi terjadi pada tahun 1992 yakni sebesar 61,05 persen menjadi Rp. 9.100 per kg dari tahun 1991 sebesar Rp. 5.650 per kg. Harga daging sapi lima tahun sebelumnya (2013 - 2017) juga terus meningkat, dari harga Rp.90.401 per kg hingga Rp. 115.779 per kg dengan pertumbuhan rata-rata 6,43 persen per tahun.

Dengan dasar tersebut, pemerintah mengambil kebijakan impor daging sapi, agar permintaan daging sapi dapat tercukupi dan menjaga stabilitas harga daging dalam negeri. Namun, efek kebijakan tersebut adalah semakin terkuranya devisa negara, dan gejolak kompetisi harga dipasar antara daging sapi kualitas local dengan daging sapi 
impor. Impor daging sapi Indonesia dari beberapa negara penghasil daging sapi. Data impor daging sapi seperti pada gambar 1 berikut ini:

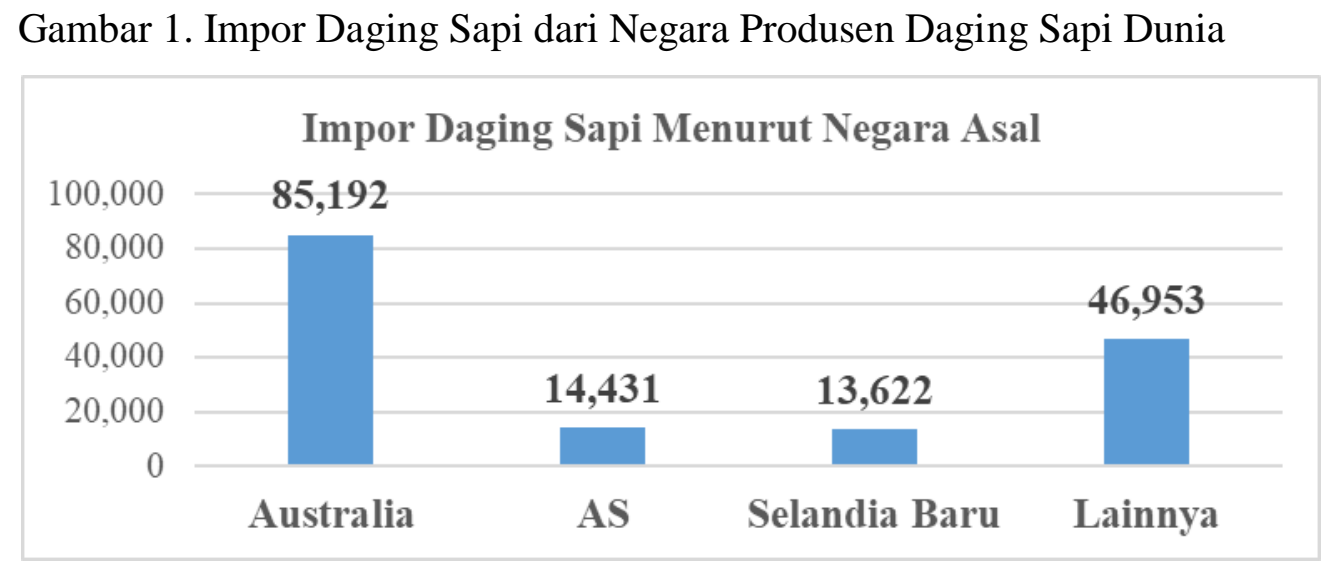

Sumber : https://www.bps.go.id, 2017

Pada tahun 2017 pemerintah melakukan impor daging sapi sekitar 160 ribu ton. Sebesar $53 \%$ daging sapi impor tersebut berasal dari Australia. Negara lain yang turut mengimpor daging sapi adalah Amerika Serikat dan Selandia Baru dengan share masing-masing sebesar $9 \%$, serta Jepang, Malaysia, dan Singapura dengan share kurang dari $1 \%$. (bps.go.id. 2017)

Tingginya angka impor pada komoditas daging sapi nasional menjadikan Indonesia sebagai Negara Net Impor. Sangat ironis dengan wilayah yang besar dan luas menjadikan Indonesia sebagai Negara Net Impor daging sapi. Data Kemeterian Pertanian menyatakan bahwa hanya 40 juta hektar, lahan yang dimanfaatkan dari luas lahan sebanyak 110 juta hektar. Kementrian Pertanian (2018).

\section{Identifikasi Masalah}

Identifikasi masalah dari penulisan ini adalah: Bagaimana perbandingan antara permintaan dan penawaran daging sapi nasional 2010-2018, Bagaimana permintaan dan penawaran daging sapi tahun 2030 berdasarkan analisis forecasting. Bagaimana perbandingan antara permintaan dan penawaran daging sapi nasional 2030. 


\section{Tujuan Penulisan}

Tujuan dari penulisan ini adalah sebagai berikut : Mengetahui perbandingan antara permintaan dan penawaran daging sapi tahun 2010-2018. Menganalisis penawaran dan permintaan daging sapi 2030 berdasarkan analisis forecasting secara nasional. Mengetahui perbandingan antara permintaan dan penawaran daging sapi 2030 secara nasional.

\section{TINJAUAN PUSTAKA}

\section{Mekanisme Pasar (Permintaan dan Penawaran Barang)}

Mekanisme pasar merupakan pertemuan antara permintaan dan penawaran untuk menentukan harga secara alamiah. Apabila permintaan naik maka harga barang-barang akan naik, begitu pula sebaliknya apabila permintaan turun harga barang-barang akan turun. Namun apabila, penawara naik harga-harga akan turun, demikian pula apabila penawaran turun harga barang-barang akan naik.

Teori penawaran dan permintaan menggambarkan atas hubungan-hubungan di pasar, antara para calon pembeli dan penjual dari suatu barang. Model penawaran dan permintaan digunakan untuk menentukan harga dan kuantitas yang terjual di pasar. Model ini memperkirakan bahwa dalam suatu pasar yang kompetitif, harga akan berfungsi sebagai penyeimbang antara kuantitas yang diminta oleh konsumen dan kuantitas yang ditawarkan oleh produsen, sehingga terciptalah keseimbangan ekonomi antara harga dan kuantitas. Model ini mengakomodasi kemungkian adanya faktor-faktor yang dapat mengubah keseimbangan, yang kemudian akan ditampilkan dalam bentuk terjadinya pergeseran dari permintaan atau penawaran.

\section{Definisi Manajemen Permintaan}

Gaspersz (2001:71) mendefinisikan manajemen permintaan (demand management) sebagai suatu fungsi pengelolaan dari semua permintaan produk untuk menjamin bahwa penyusunan jadwal induk (master scheduler) mengetahui dan menyadari semua permintaan produk itu. Secara garis besar aktivitas-aktivitas dalam manajemen permintaan dapat dikategorikan ke dalam dua aktivitas utama, yaitu pelayanan pesanan (order service) yang bersifat pasti, dan peramalan (forecasting) yang bersifat tidak pasti. 


\section{Kebijakan Pemerintah}

Kebijakan pemerintah adalah pemilihan sebuah alternatif terbaik dari sekian banyak alternatif yang bersaing satu sama lain untuk mendominasi yang lainnya, kegiatan ini berlangsung terus menerus. Hal ini sangat penting untuk mengatasi keadaan pemerintah, pembangunan dan kemasyrakatan. Masyarakat biasanya lebih menilai apa yang tidak dilaksanakan dibandingkan melakukan penilaian terhadap apa yang telah dilaksanakan oleh pemerintah.

Kebijakan Pemerintah dapat menciptakan situasi dan kondisi, dapat pula terjadi sebaliknya bahwa kebijakan pemerintah diciptakan oleh situasi dan kondisi. Dimana perhatian utama kepemimpinan pemerintah adalah public policy (kebijakan pemerintah), yaitu apapun juga yang dipilih pemeritah, apakah mengerjakan sesuatu itu, ataukah tidak mengerjakan sama sekali (mendiamkan) sesuatu itu. Dye (1978).

\section{Sapi}

Sapi merupakan hewan ruminansia yang pada umumnya herbivora atau pemakan tanaman, sehingga seebagian besar makanannya adalah selulose, hemiselulose, dan bahkan lignin yang semuanya dikategorikan sebgai serat kasar. Hewan ini disebut juga hewan berlambung jamak atau polygastic animal, karena lambungnya terdiri atas rumen, retikulum, omasum dan abomasum (Sembiring, 2010).

\section{Sapi Potong}

Dari beberapa jenis sapi lokal Indonesia yang layak dijadikan sumber pedaging seperti sapi bali, sapi PO dan sapi madura kebutuhan akan daging sapi setiap tahun cenderung meningkat. Pada tahun 2017, jumlah komsusi daging sapi sebesar 687.088.964,48. Sementara itu, pada tahun 2018 kebutuhan daging sapi meningkat hingga 708.056.222,24, mengalami peningkatan sebesar 20.967.257,76 atau 49,25\%.

\section{Analisis Forecasting}

Heizer \& Render (2011:139) menjelaskan bahwa metode forecast dilakukan dengan menggunakan model matematis yang beragam dengan data historis yang terkait dengan peramalan dan variabel sebab akibat untuk meramalkan permintaan. Metode 
peramalan kuantitatif dibagi menjadi dua jenis, yaitu Time Series Forecasting dan Associative Forecasting Method. Pada penulisan ini menggunakan Time Series Forecasting.

Time series method merupakan analisis deret waktu yang terdiri dari trend, seasonal, cycle, dan random variation. Analisis deret waktu ini sangat tepat dipakai untuk meramalkan permintaan yang pola permintaan di masa lalunya cukup konsisten dan akurat dalam periode waktu yang lama.

\section{Kerangka Pemikiran}

Komoditas daging sapi merupakan salah satu komoditi pangan yang memiliki peranan penting dalam menentukan ketersediaan pangan di masyarakat. Analisis forecasting penawaran daging sapi merupakan analisis untuk mengetahui berapakah penawaran sapi tahun tertentu, analisis meramalkan penawaran daging sapi dipengaruhi oleh produksi daging sapi dan impor daging sapi.

Untuk mengetahui berapa sisi penawaran dan berapa sisi permintaan daging sapi pada tahun 2030, maka dapat dianalisis melalui data ketersediaan daging sapi pada tahun 2010-2018. Dimana ketersediaan daging sapi dilihat dari dua faktor yaitu penawaran daging sapi tahun 2010-2018 dan impor daging sapi dari tahun 2010-2018. Dengan data dan perhitungan forecasting pada tahun 2010-2018 tersebut maka akan diketahui pola permintaan daging sapi pada tahun 2030 dan penawaran daging sapi tahun 2030.

\section{METODE}

\section{Metode Lokasi Penelitian dan Pengumpulan Data}

Metode pengumpulan data dilakukan melalui studi pustaka dan dokumentasi. Data yang digunakan data sekunder. Data sekunder diperoleh dari buku-buku literatur, jurnal-jurnal menganai konsumsi dan produksi sapi dalam angka terbitan BPS dan Dinas Peternakan yang berkaitan dengan penulisan ini.

\section{Metode Analisis Data}

Metode analisis data yang digunakan dalam penelitian ini adalah,: hipotesis 1 . menggunakan metode deskriptif dengan menyajikan data dalam bentuk tabel dan grafik 
sehingga dapat dilihat perbandingan antara penawaran daging sapi, permintaan daging sapi dan impor daging sapi pada tahun 2010-2018. Hipotesis 2. menggunakan analisis data kuantitatif untuk forecasting dengan menggunakan metode kuadrat terkecil serta menggunakan metode deskriptif dengan menyajikan data dalam bentuk tabel dan grafik sehingga dapat dilihat perbandingan antara penawaran dengan permintaan daging sapi nasional 2030.

Adapun metode yang dapat digunakan untuk menganalisis data tersebut, yaitu: Trend Projection (Proyeksi Tren), yakni sebuah Metode yang digunakan untuk mencocokkan garis tren pada serangkaian data masa lalu, kemudian memproyeksikan garis pada masa depan untuk peramalan jangka menengah atau jangka panjang. Garis tren pada metode proyeksi tren dapat dinyatakan dengan persamaan sebagai berikut:

$$
\hat{y}=a+b x
$$

Untuk garis kemiringan $\mathrm{b}$ dapat ditemukan dengan persamaan:

$$
\begin{gathered}
\mathrm{b}=\frac{\sum x y-n \bar{x} \bar{y}}{\sum x^{2}-n \bar{x}^{2}} \\
a=\bar{y}-b \bar{x} \\
\bar{x}=\frac{\sum x}{n} \\
\bar{y}=\frac{\sum y}{n}
\end{gathered}
$$

Keterangan:

$\hat{y}=$ variabel terikat yang akan diprediksi,

$a=$ persilangan sumbu $\mathrm{y}$,

$b=$ kemiringan garis regresi,

$x=$ variabel bebas,

$\mathrm{n}=$ jumlah data atau pengamatan,

$\bar{x}=$ rata-rata nilai $\mathrm{x}$,

$\bar{y}=$ rata-rata nilai $\mathrm{y}$. 


\section{HASIL DAN PEMBAHASAN}

\section{Perbandingan Produksi dan Konsumsi Daging Sapi 2010-2018}

Untuk mengetahui penawaran daging sapi, maka akan diperoleh dengan melakukan analisis forecasting yaitu dengan menggunakan data penawaran dan permintaan daging sapi nasional tahun 2010-2018. dimana pola permintaan dan penawaran seperti pada tabel 2 .

Tabel 2. Perbandingan Penawaran dan Permintaan Daging Sapi Nasional

Tahun 2010-2018

\begin{tabular}{cccc}
\hline Tahun & Penawaran & Permintaan & Rasio \\
\hline 2010 & $436.450 .000,00$ & $392.168 .240,79$ & 1,113 \\
2011 & $485.335 .000,00$ & $422.477 .051,41$ & 1,149 \\
2012 & $508.905 .000,00$ & $445.166 .469,04$ & 1,143 \\
2013 & $504.819 .000,00$ & $495.079 .804,86$ & 1,020 \\
2014 & $497.669 .000,00$ & $541.767 .952,96$ & 0,919 \\
2015 & $506.660 .000,77$ & $583.272 .004,48$ & 0,869 \\
2016 & $518.484 .000,03$ & $649.258 .549,70$ & 0,799 \\
2017 & $486.320 .000,00$ & $687.088 .964,48$ & 0,708 \\
2018 & $496.302 .000,00$ & $708.056 .222,24$ & 0,701 \\
\hline
\end{tabular}

Keterangan :

Rasio $=<1 \quad$ : Komsusi lebih tinggi dibandingkan produksi

Rasio $=\geq 1 \quad:$ Produksi lebih tinggi dibandingkan konsumsi

Sumber : data sekunder diolah 2019

Pada tabel 2, diketahui bahwa pada tahun 2010 sampai tahun 2013 penawaran daging sapi secara nasional lebih tinggi dibandingkan sisi permintaan, ketersediaan komoditas dipasar mampu mencukupi permintaan daging sapi masyarakat. Namun, sejak tahun 2014 sampai 2018 sisi penawaran daging sapi nasional mengalami fluktuatif, tetapi disisi permintaan terjadian kenaikan secara konsisten.

Menurunnya sisi penawaran di tahun 2014 lebih banyak disebabkan adanya fenomena kesejahteraan hewan, (ditahun 2014 banyak terjadi penyakit kuku dan mulut pada negara produsen sapi potong dunia, sehigga pemerintah mengambil kebijakan untuk mengurangi impor daging sapi dan sapi bakalan), dan label halal daging sapi impor (pemerintah mencoba mengambil kebijakan untuk mengimpor daging sapi dari 
negara Cina, namun proses pengolahan daging sapi potong di Cina belum terakreditasi halal layaknya Australia dan Amerika Serikat).

\section{Analisis Forecasting}

\section{a. Analisis Forecasting Penawaran Daging Sapi}

Pola Penawaran daging sapi hingga tahun 2030 diperoleh dengan analisis forecasting menggunakan data penawaran daging sapi tahun 2009-2018, sehingga diperoleh persamaan Trend Linier sebagai berikut:

$$
\mathrm{Y}=493.438 .222,31+4.389 .367 \mathrm{X}
$$

Dari hasil persamaan tersebut maka, diproyeksikan penawaran daging sapi pada tahun 2019 sampai 2013, seperti pada tabel 3, yakni:

Tabel. 3 Proyeksi Penawaran Daging Sapi Nasional 2019-2030

\begin{tabular}{ccccc}
\hline No & Tahun & $\mathbf{X}$ & Penawaran & Kenaikan (\%) \\
\hline 1 & 2019 & 10 & $537.331 .889,12$ & 1,01 \\
2 & 2020 & 11 & $541.721 .255,80$ & 1,01 \\
3 & 2021 & 12 & $546.110 .622,48$ & 1,01 \\
4 & 2022 & 13 & $550.499 .989,16$ & 1,01 \\
5 & 2023 & 14 & $554.889 .355,84$ & 1,01 \\
6 & 2024 & 15 & $559.278 .722,52$ & 1,01 \\
7 & 2025 & 16 & $563.668 .089,20$ & 1,01 \\
8 & 2026 & 17 & $568.057 .455,88$ & 1,01 \\
9 & 2027 & 18 & $572.446 .822,56$ & 1,01 \\
10 & 2028 & 19 & $576.836 .189,24$ & 1,01 \\
11 & 2029 & 20 & $581.225 .555,92$ & 1,01 \\
12 & 2030 & 21 & $585.614 .922,60$ & - \\
\hline \multicolumn{5}{c}{ Sumber: Hasil Analisis Forecasting. 2019}
\end{tabular}

Dari persamaan yang diperoleh maka dapat diketahui penawaran daging sapi untuk tahun 2019-2030 dengan menggantikan nilai x di persamaan dengan nilai x yang telah ditentukan untuk tahun tersebut. Persamaan yang diperoleh menunjukkan adanya 
trend meningkat, setiap tahun terjadi peningkatan ketersediaan daging sapi secara ratarata yaitu sebesar $>4.389$ Ton.

Pada sisi penawaran daging sapi pada tahun 2019-2030 mengalami peningkatan yang yang konsisten yaitu dengan rata-rata pertumbuhan sebesar 4.389 Ton dengan peningkatan rata-rata 1,01. Hasil dari analisis forecasting hanya menggunakan data tahun penawaran 2010-2018, dengan demikian faktor-faktor lain diasumsikan konstan. Faktor-faktor lain tersebut diantarannya adalah apabila pemerintah menaikan kuota impor daging sapid an hasil turunannya, serta adanya intensif bagi para rumah tangga peternak, sehingga produktifitas meningkat.

\section{b. Analisis Forecasting Permintaan Daging Sapi Nasional}

Pola permintaan daging sapi nasional hingga tahun 2030 diperoleh dengan analisis forecasting menggunakan data permintaan daging sapi dari tahun 2010-2018, sehingga diperoleh persamaan trend linier:

\section{$Y=11.607,27+1.113,74 X$}

Dari persamaan yang diperoleh maka dapat diketahui konsumsi daging sapi untuk tahun 2010 - 2018 dengan menggantikan nilai $\mathrm{x}$ di persamaan dengan nilai $\mathrm{x}$ yang telah ditentukan untuk tahun tersebut. Persamaan yang diperoleh menunjukkan adanya trend meningkat, setiap tahun terjadi peningkatan konsumsi daging sapi secara rata-rata yaitu sebesar 1.113,74 ton. Hasil perhitungan dengan analisis forecasting seperti tertera pada tabel 4, yakni: 
Tabel 3. Total Proyeksi Konsumsi Daging Sapi Nasional 2019-2030

\begin{tabular}{cccc}
\hline Tahun & X & Permintaan & Kenaikan (\%) \\
\hline 2019 & 10 & $972.775 .699,88$ & 1,04 \\
2020 & 11 & $1.015 .338 .433,64$ & 1,04 \\
2021 & 12 & $1.057 .901 .167,41$ & 1,04 \\
2022 & 13 & $1.100 .463 .901,17$ & 1,04 \\
2023 & 14 & $1.143 .026 .634,94$ & 1,04 \\
2024 & 15 & $1.185 .589 .368,71$ & 1,04 \\
2025 & 16 & $1.228 .152 .102,47$ & 1,03 \\
2026 & 17 & $1.270 .714 .836,24$ & 1,03 \\
2027 & 18 & $1.313 .277 .570,00$ & 1,03 \\
2028 & 19 & $1.355 .840 .303,77$ & 1,03 \\
2029 & 20 & $1.398 .403 .037,53$ & 1,03 \\
2030 & 21 & $1.440 .965 .771,30$ & - \\
\hline
\end{tabular}

Sumber: Hasil Perhitungan Forecasting, 2019

Pada tabel 4, dapat dilihat bahwa sisi permintaan daging sapi nasional tahun 2019-2024 mengalami kenaikan secara konsisten, dengan rata-rata kenaikan sebesr 1,01\% sedangkan di tahun 2025 terjadi penurunan permintaan daging sapi secara nasional dengan rata-rata $1,03 \%$. Kenaikan dari sisi permintaan di mungkinkan dengan bertambahnya jumlah penduduk secara nasional.

\section{c. Perbandingan Penawaran dan Permintaan Daging Sapi Nasional 2019-2030}

Mekanisme pasar merupakan tempat mempertemukan antara sisi permintaan (konsumen) dengan sisi penawaran (produsen), dimana keduanya saling berinteraksi untuk melakukan transaksi untuk tercapai kepuasan kedua belah pihak. Kepuasan dari konsumen (permintaan) adalah apa yang menjadi kebutuhannya dapat tercukupi, sedangkan kepuasan di pihak produsen (Penawaran) dapat memaksimalkan harga untuk meraih laba.

Adanya analisis forecasting diharapkan terjadi keseimbangan antara permintaan dan penawaran sehingga akan terbentuk keseimbangan pasar, yang mempunyai komponen keseimbangan harga dan keseimbangan kuantitas. Proyeksi penawaran dan 
permintaan daging sapi nasional, yang didapatkan dari perhitungan analisis forecasting seperti pada tabel 5, yakni:

Tabel 5. Hasil Analisis Forecasting Total Penawaran dan Permintaan Daging Sapi Nasional 2019-2030

\begin{tabular}{cccccc}
\hline Tahun & X & Penawaran & Permintaan & Selisih & Rasio \\
\hline 2019 & 10 & $537.331 .889,12$ & $972.775 .699,88$ & $(435.443 .810,76)$ & 0,552 \\
2020 & 11 & $541.721 .255,80$ & $1.015 .338 .433,64$ & $(473.617 .177,85)$ & 0,534 \\
2021 & 12 & $546.110 .622,48$ & $1.057 .901 .167,41$ & $(511.790 .544,93)$ & 0,516 \\
2022 & 13 & $550.499 .989,16$ & $1.100 .463 .901,17$ & $(549.963 .912,02)$ & 0,500 \\
2023 & 14 & $554.889 .355,84$ & $1.143 .026 .634,94$ & $(588.137 .279,10)$ & 0,485 \\
2024 & 15 & $559.278 .722,52$ & $1.185 .589 .368,71$ & $(626.310 .646,19)$ & 0,472 \\
2025 & 16 & $563.668 .089,20$ & $1.228 .152 .102,47$ & $(664.484 .013,27)$ & 0,459 \\
2026 & 17 & $568.057 .455,88$ & $1.270 .714 .836,24$ & $(702.657 .380,36)$ & 0,447 \\
2027 & 18 & $572.446 .822,56$ & $1.313 .277 .570,00$ & $(740.830 .747,44)$ & 0,436 \\
2028 & 19 & $576.836 .189,24$ & $1.355 .840 .303,77$ & $(779.004 .114,53)$ & 0,425 \\
2029 & 20 & $581.225 .555,92$ & $1.398 .403 .037,53$ & $(817.177 .481,61)$ & 0,416 \\
2030 & 21 & $585.614 .922,60$ & $1.440 .965 .771,30$ & $(855.350 .848,70)$ & 0,406 \\
\hline
\end{tabular}

Sumber: Hasil Perhitungan Forecasting, 2019

Tampak pada tabel 5 di atas perbedaan yang sangat mencolok antara proyeksi permintaan dan penawaran daging sapi nasional hingga tahun 2019-2030. Puncaknya pada tahun 2030, tanpa ada upaya terpadu dari semua pihak maka defisit daging sapi nasional mencapai lebih dari > 855,250 ton. Periode tahun 2019 sampai 2030, sisi penawaran mencapai rata-rata \pm 561.473 ton per tahun, sedangkan sisi permintaan pada periode yang sama didapatkan rata-rata \pm 1.206 .871 ton per tahun, sehingga pola penawaran daging sapi nasional mengalami deficit rata-rata sebesar \pm 645.397 ton per tahun.

Tabel 4, memperlihatkan bahwa di tahun 2019 sisi permintaan daging sapi secara nasional mencapai 972.775 ton, namun sisi penawaran hanya mampu menyediakan kebutuhan daging sapi nasional sebesar 537.331 ton, sehingga daging sapi nasional, dari sisi penawaran mengalami kekurangan sebesar 435.443 ton. Pada tahun 2020 sisi permintaan daging sapi secara nasional mencapai 1.015 .338 ton, namun sisi penawaran hanya mampu menyediakan kebutuhan daging sapi nasional sebesar 541.721 
ton, sehingga daging sapi nasional, dari sisi penawaran mengalami kekurangan sebesar 473.517 ton.

Pada tahun 2021 sisi permintaan daging sapi secara nasional mencapai 1.057.901. ton, namun sisi penawaran hanya mampu menyediakan kebutuhan daging sapi nasional sebesar 546.110 ton, sehingga daging sapi nasional, dari sisi penawaran mengalami kekurangan sebesar 511.790 ton. Periode tahun 2022 sisi permintaan daging sapi secara nasional mencapai 1.100 .463 ton, namun sisi penawaran hanya mampu menyediakan kebutuhan daging sapi nasional sebesar 550.499 ton, sehingga daging sapi nasional, dari sisi penawaran mengalami kekurangan sebesar 549.963 ton.

Pada tahun 2023 sisi permintaan daging sapi secara nasional mencapai 1.143.026 ton, namun sisi penawaran hanya mampu menyediakan kebutuhan daging sapi nasional sebesar 554.889 ton, sehingga daging sapi nasional, dari sisi penawaran mengalami kekurangan sebesar 588.137 ton. Periode tahun 2024 sisi permintaan daging sapi secara nasional mencapai 1.185 .589 ton, namun sisi penawaran hanya mampu menyediakan kebutuhan daging sapi nasional sebesar 559.278 ton, sehingga daging sapi nasional, dari sisi penawaran mengalami kekurangan sebesar 626.310 ton.

Pada tahun 2025 sisi permintaan daging sapi secara nasional mencapai 1.228.152 ton, namun sisi penawaran hanya mampu menyediakan kebutuhan daging sapi nasional sebesar 563.668 ton, sehingga daging sapi nasional, dari sisi penawaran mengalami kekurangan sebesar 664.484 ton. Periode tahun 2026 sisi permintaan daging sapi secara nasional mencapai 1.270 .714 ton, namun sisi penawaran hanya mampu menyediakan kebutuhan daging sapi nasional sebesar 568.057 ton, sehingga daging sapi nasional, dari sisi penawaran mengalami kekurangan sebesar 855.350 ton.

Perode tahun 2027 sisi permintaan daging sapi secara nasional mencapai 972.775 ton, namun sisi penawaran hanya mampu menyediakan kebutuhan daging sapi nasional sebesar 537.331 ton, sehingga daging sapi nasional, dari sisi penawaran mengalami kekurangan sebesar 435.443 ton. Pada tahun 2028 sisi permintaan daging sapi secara nasional mencapai 972.775 ton, namun sisi penawaran hanya mampu menyediakan kebutuhan daging sapi nasional sebesar 537.331 ton, sehingga daging sapi nasional, dari sisi penawaran mengalami kekurangan sebesar 435.443 ton.

Pada tahun 2029 sisi permintaan daging sapi secara nasional mencapai 1.398.403 ton, namun sisi penawaran hanya mampu menyediakan kebutuhan daging 
sapi nasional sebesar 581.225 ton, sehingga daging sapi nasional, dari sisi penawaran mengalami kekurangan sebesar 817.177 ton. Tahun 2030 sisi permintaan daging sapi secara nasional mencapai 1.440 .965 ton, namun sisi penawaran hanya mampu menyediakan kebutuhan daging sapi nasional sebesar 585.615 ton, sehingga daging sapi nasional, dari sisi penawaran mengalami kekurangan sebesar 855.351 ton.

Perhitungan pada penulisan ini hanya mengukur dan memproyeksikan sisi produksi dan komsusi daging nasional, dari tahun 2010 sampai 2018, tanpa memperhatikan variabel/faktor-faktor lain. Karena variabel lain dianggap konstan. Pemerintah selaku pembuat kebijakan hendaknya membuat kebijakan yang lebih komperensif menyangkut produksi daging sapi nasional demi terwujudnya swasembada daging sapi nasional.

\section{KESIMPULAN DAN SARAN}

\section{Kesimpulan}

1. Perbandingan sisi penawaran dan sisi permintaan daging sapi nasional periode tahun 2019-2030, menunjukan trend meningkat dan konsisten. Analisis forecasting menghasilkan bahwa sisi penawaran daging nasional mengalami peningkatan namun tidak mampu memenuhi permintaan dalam negeri sehingga rasionya $<1$.

2. Hasil analisis forecasting menunjukkan bahwa ketersediaan daging sapi dan konsumsi daging sapi pada tahun 2030 mengalami trend kenaikan serta perbandingan antara penawaran dengan permintaan daging sapi Nasional 2030 menunjukkan ratio permintaan daging sapi lebih besar dibandingkan dengan penawaran daging sapi yaitu ratio $>1$, sehingga program swasembada daging sapi tertunda.

\section{Saran}

Dari hasil penelitian dapat diberikan saran kepada pihak-pihak berikut ini:

1. Saran Kepada Pemerintah, diharapkan membuat suatu kebijakan yang dapat menjamin permintaan daging sapi dengan meningkatkan posisi penawaran (produksi) daging sapi.

2. Saran Kepada Peternak, diharapkan untuk dapat meningkatkan produksi daging sapi untuk dapat mendukung ketersediaan daging sapi. 
3. Saran Kepada Peneliti Selanjutnya, diharapkan agar dapat meneliti bagaimana ketersediaan daging sapi dalam mendukung swasembada daging sapi pada tahun berikutnya. Agar dapat diketahui bagaimana ketersediaan daging sapi nasional selanjutnya dalam rangka program swasembada daging sapi.

\section{DAFTAR PUSTAKA}

Abidin, SZ. 2004. Kebijakan Publik Edisi Revisi, Yayasan Pancur Siwah, Jakarta.

Arsyad, Lincolin. 1999. Pengantar Perencanaan dan Pembangunan Ekonomi Daerah. BPFE. Jogyakarta.

Badan Pusat Statistik. 2018. Proyeksi Penduduk Indonesia 2015-2045. BPS. Jakarta. Indonesia

Bendavid. 1991. Regional and Local Economic Analysis for Practioners. New York. Praeger Publisher Inc.

Dye, R. Thomas, 1978, Understanding Publik Policy, Prentice - Hall, Inc, Englewood Cliffs, New Jersey.

Kementrian Perdagangan. 2014. Laporan Ringkas Analisis Out Look Pangan 20152019. Pusat Kebijakan Perdagangan Dalam Negeri Badan Pengkajian dan Pengembangan Kebijakan Perdagangan. Jakarta. Indonesia

Laoli, N. 2011. Swasembada Daging Terancam. Kompas. Jakarta.

Moeljono. 2012. Pengaruh Bantuan Sosisal Ternak Sapi Potong Untuk Peningkatan Pendapatan Kelompok Tani Ternak di Kabupaten Semarang-Jawa Tengah. Tesis (Tidak dipublikasikan) Magister Agribisnis Universitas Diponegoro.

Santoso, S. 2009. Business Forecasting Metode Peramalan Bisnis Masa Kini dengan MINITAB dan SPSS. PT. Elex Media Komputindo. Jakarta

Sjafrizal. 1997. Pertumbuhan Ekonomi dan Ketimpangan Regional Wilayah Indonesia Bagian Barat. Prisma Lembaga Penelitian, Pendidikan dan Penerangan Ekonomi \& Sosial. No.3, 27-38.

Sjafrizal. 2008. Ekonomi Regional, Teori dan Aplikasi. Boduose Media. Padang. Sumatera Barat.

Soenarko, 2005. Sosial dan Lingkungan. LP3ES. Jakarta.

Sugiarto dan Harijono, 2000.Peramalan Bisnis. PT. Gramedia. Jakarta.

Tarigan, R. 2005. Ekonomi Regional. PT Bumi Aksara. Jakarta 